\title{
PENGARUH VARIASI KONSENTRASI EKSTRAK SERAI (Andropogon nardus) TERHADAP MORTALITAS HAMA KEONG MAS (Pomaceacaniculata L.)
}

\author{
Sang Putra ${ }^{1}$ \\ Suharno Zein, M.Sc ${ }^{2}$ \\ Pendidikan Biologi IAIN Raden Intan Bandar Lampung \\ Dosen Universitas Muhammadiyah Metro2 \\ suharnozein@gmail.com
}

\begin{abstract}
Snails (Pomaceae canaliculata L) or often referred to as snail mulberry is one type of freshwater snail that comes from the Americas. The spread of snails (Pomaceae canaliculata L.) in Indonesia the spread widening due to breeding very fast. Besides, many snails are farmed in ponds so many move to the rice fields. Potential snails can cause crop damage ranges from 10-40\%. The aim of this study was to determine the concentration of extract of lemon grass (Andropogon nardus) most appropriate for mortalty pest snails (Pomacea caniculata L.). This study was conducted in July to September 2014 in Biology Laboratorium State Islamic Institute (IAIN) Raden Intan Lampung. This type of research is experimental. The method used in the study is the method of full randomized design (CRD) with three repetitions each cup contains 12 heads snails. The concentration of treatment were 0\% (as a control), $2 \%, 3 \%, 4 \%, 5 \%$. Based on the results of the study showed that:The concentration of the most effective in killing pests snails Pomacea caniculata $L$ is 5\%, which is able to kill $100 \%$ of pest snails Pomacea caniculata L for 24 hours. Sitronela compounds have the nature of a contact poison that can cause death due to loss of fluid continuously.
\end{abstract}

Kata kunci: Mortalitas, ekstrak, kontak racun.

Keong mas (Pomaceae canaliculata L) ada juga yang menyebut siput murbei merupakan salah satu jenis keong air tawar yang berasal dari Benua Amerika, tidak jelas mulai kapan masuk ke wilayah Indonesia. Keong mas secara bebas di pasaranpada tahun 1981 diYogyakarta telah dijualbelikan sebagai hiasan karena bentuk dan warnanya yang menarik. Adanya banyak keong mas yang dijualbelikan pada masyarakat maka penyebaran keong mas makin meluas karena perkembangnbiakannya sangat cepat. Disamping itu banyak keong mas yang dibudidayakan di kolam-kolam sehingga banyak yang menuju ke persawahan. Potensi keong mas dapat menyebabkan kerusakan tanaman berkisar 10-40\%, daerah penyebaran di wilayah Indonesia antara lain Jawa, Sumatra, Kalimantan, NTB dan Bali.

Keong mas sangat menyukai lingkungan yang jernih, mempunyai suhu air antara 10-35 C, dengan demikian mudah ditemukan di daerah sawah, waduk, situ, rawa dan genangan air (Riyanto, 2003). Keong mas bersifat herbivor yang memakan segala tanaman dan sangat rakus.Keong mas (Pomacea canaliculata) merupakan salah satu hama utama tanaman padi dengan cara merusak tanaman dengan memakan jaringan tanaman. Bekas potongan daun dan batang padi yang diserangnya terlihat mengambang. Waktu kritis untuk mengendalikan 
hama keong mas pada saat 10 hari setelah tanam pindah, atau 21 hari setelah sebar benih (benih basah). Setelah itu laju pertumbuhan tanaman lebih besar daripada laju kerusakan oleh keong mas (Ben, 2004). Apabila habitatnya dalam keadaan kekurangan air maka keong mas akan membenamkan diri pada lumpur yangdalam, hal ini dapat bertahan selama beberapa bulan. Bila habitatnya sudah ada airnya maka keong mas akan muncul kembali pada saat pengolahan lahan. Keong mas mempunyai jenis kelamin yaitu jantan dan betina, tidak seperti jenis siput yang lain. Keong mas siap melakukan kopulasi pada saat kondisi air terpenuhi pada areal persawahan. Tentang fisiologis keong mas, Budiyono(2012) menjelaskan bahwa keong mas memiliki alat pernapasan berupa paru-paru dan insang yang digunakan setiap saat pada lingkungan yang berbeda. Waktu yang dibutubkan pada fase telur yaitu 1-2 minggu, pada pertumbuhan awal membutuhkan waktu 2-4 minggu lalu menjadi siap kawin pada umur 2 bulan. Keong mas dewasa berwarna kuning keemasan.

Dalam satu kali siklus hidupnya memerlukan waktu antara 2-2,5 bulan. Keong mas dapat mencapai umur kurang lebih 3 tahun. Cara menyerang keong mas pada tanaman padi yaitu tanaman padi yang baru ditanam sampai 15 hari setelah tanam mudah dirusak keong mas, untuk padi tanam benih langsung (tabela) ketika 4 sampai 30 hari setelah tebar. Keong mas melahap pangkal bibit padi muda. Keong mas mengkonsumsi seluruh tanaman muda dalam satu malam lalu rumpun yang hilang, adanya potongan daun yang mengambang di permukaan air. Telur keong mas diletakkan secara berkelompok berwarna merah jambu seperti buah murbei sehingga disebut juga keong murbei.

Keong mas selama hidupnya mampu menghasilkan telur sebanyak 15-20 kelompok, yang tiap kelompok berjumlah kurang lebih 500 butir, dengan persentase penetasan lebih dari 85\% (Rusdy, 2010). Hal ini menimbulkan kerugian yang besar bagi para petani sehingga perlu dikendalikan populasinya. Sejauh ini pengendalian hama tumbuhan umumnya menggunakan pestisida sintetik. Menurut Kardinan (2013), penggunaan pestisida sintetik merupakan metode umum dalam upaya pengendalian hama dan penyakit yang menyerang tanaman pertanian.

Kebanyakan pestisida sintetik memiliki sifat non spesifik, yaitu tak hanya membunuh jasad sasaran tetapi juga membunuh organisme lain yang bukan sasaran. Pestisida sintetik dianggap sebagai bahan pengendali hama penyakit yang paling praktis, mudah diperoleh, mudah dikerjakan dan hasilnya cepat terlihat. Padahal penggunaannya sering menimbulkan masalah seperti pencemaran lingkungan, keracunan terhadap manusia dan hewan peliharaan dan dapat mengakibatkan resistensi.Serai merupakan tanaman yang memiliki kandungan efektif sitronelal 32-45\%, geraniol $12-18 \%$, sitronelol $11-15 \%$, geranil asetat 3-8\%, sitronelil asetat 2$4 \%$, sitral, kavikol, eugenol, elemol, kadinol, kadinen, vanilin, limonen, kamfen. Kandungan senyawa serai yang paling besar adalah sitronela yaitu sebesar 35\%. Senyawa sitronela mempunyai sifat racun kontak yang dapat mengakibatkan kematian karena kehilangan cairan terus menerus (Budiarsih, 2011). 


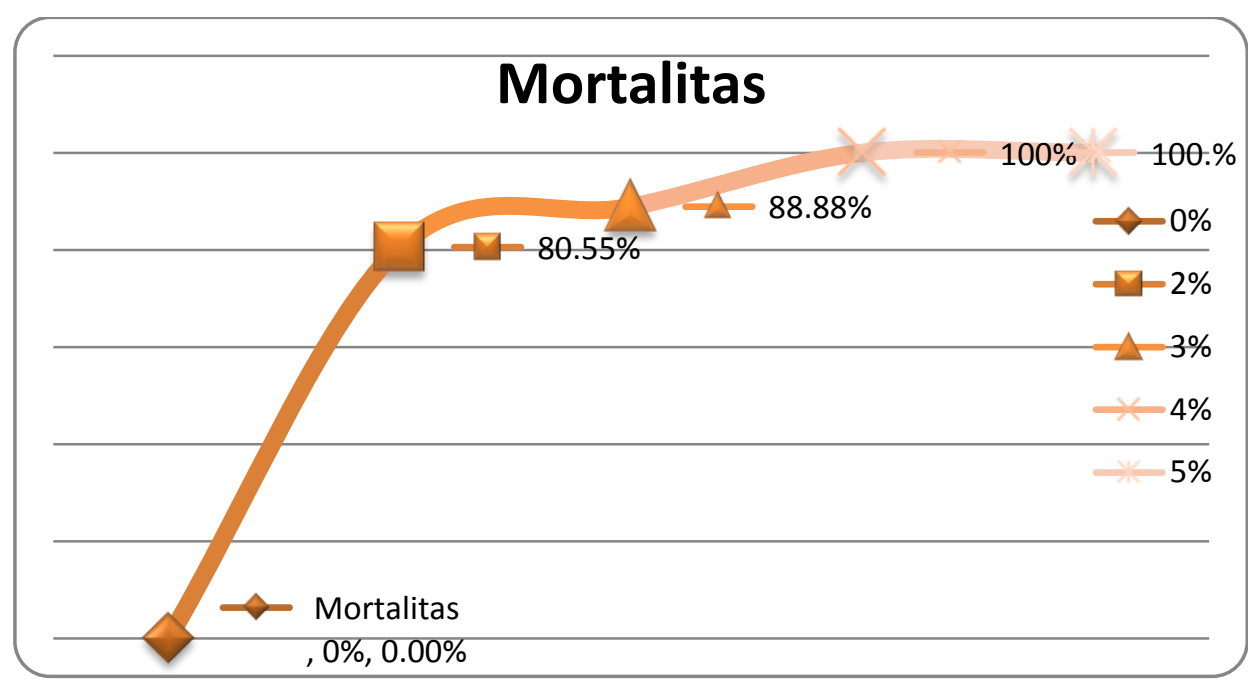

Gambar 1. Grafik hubungan antara konsentrasi dan mortalitas hama uji
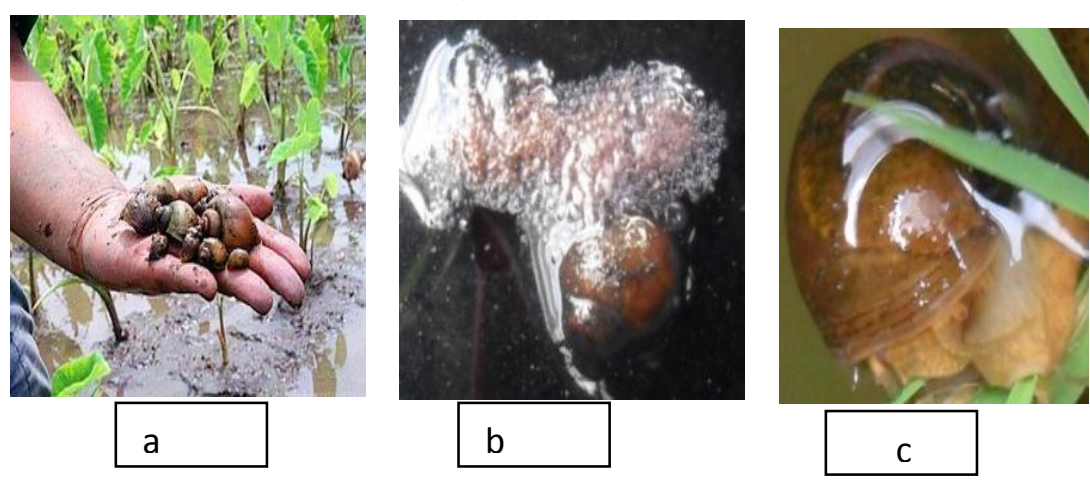

Gambar 2.

a. Keong emas sehat

b Keong emas yang mati pada awal kematian

c. Keong emas yang mati pada akhir pengamatan

Sumber: Dokumentasi pribadi, 2014

\section{METODE}

Jenis penelitian adalah eksperimental untuk mengetahui efektivitas batang serai (Andropogon nardus) terhadap mortalitas hama keong mas (Pomacea caniculata $L)$.Metode yang digunakan dalam penelitian adalah metode Rancangan Acak lengkap (RAL). Percobaan dilakukan dengan tiga kali pengulangan yang mana masingmasing gelas berisi 12 ekor keong mas. Konsentrasi perlakuan adalah 0\% (sebagai kontrol), 2\%, 3\%, 4\%, 5\%.

Dalam setiap perlakuan dibuat ulangan sebanyak 3 kali dengan waktu pengamatan setiap 2 jam selama 24 jam pengamatan. Hama keong mas yang dinyatakan mati jika keong mas tidak ada gerakan lagi, berada di dasar air, daging keluar dari cangkang, dan keluarnya lendir dari permukaan cangkang. Efektivitas ekstrak batang serai wangi (Andropogon nardus) di analisis mengunakan uji statistik analisis varians (Anova) dengan menggunakan program SPSS 17 dan untuk mengetahui perlakuan mana yang berpengaruh paling baik dilanjutkan dengan uji LDS taraf 5\%.

\section{HASIL}

Pengaruh variasi konsentrasi ekstrak serai (Andropogon nardus) 
terhadap mortalitas hama keong mas (Pomaceacaniculata L.)

Berdasarkan gambar 1 terlihat hubungan antara konsentrasi dan hama ji, jumlah mortalitas hama uji keong mas dipengaruhi oleh peningkatan konsentrasi ekstrak, semakin tinggi ekstrak yang digunakan maka jumlah mortalitas semakin tinggi. Mortalitas terendah pada penelitian ini terdapat pada perlakuan kontrol $\left(\mathrm{P}_{0}\right)$ 0\%mortalitas hama uji keong mas $0.00 \%$. Pada perlakuan $\left(\mathrm{P}_{1}\right)$ $2 \%$ mortalitas hama uji keong mas $80.55 \%$. Pada perlakuan $\left(\mathrm{P}_{2}\right) \quad 3 \%$ mortalitas hama uji keong mas $88.88 \%$. Pada perlakuan $\left(\mathrm{P}_{3}\right) \quad 4 \%$ mortalitas hama uji keong mas $100 \%$ dan perlakuan $\left(\mathrm{P}_{4}\right) 5 \%$ mortalitas hama uji keong mas 100\%.Peningkatan mortalitas hama uji keong mas terjadi pada perlakuan $4 \%$ dan $5 \%$.

Dihitung dari hasil analisis One Way Anova, menunjukkan bahwa ada pengaruh yang berbeda nyata dari pemberian ekstrak serai wangi (Andropogon nardus) terhadap mortalitas hama keong mas (Pomacea canicullata). Dengan demikian dapat disimpulkan bahwa ekstrak serai wangi (Andropogon nardus) berpengaruh secara signifikan terhadap mortalitas hama keong mas (Pomacea canicullata) dengan nilai $\mathrm{p}=0,00$ $(\mathrm{p}=0,05)$. Selanjutnya untuk mengetahui perlakuan mana yang paling berpengaruh paling baik dalam penelitian maka dilanjutkan dengan menggunakan uji LSD dengan tarap kepercayaan 5\%. Berdasarkan dari hasil uji LSD pada taraf 5\% menunjukkan hasil berbeda nyata dari pemberian ekstrak serai wangi (Andropogon nardus) terhadap mortalitas hama keong mas (Pomacea canicullata). Pada perlakuan kontrol (P0) diperoleh hasil berbeda nyata dengan semua perlakuan yaitu perlakuan P1, P2, P3, dan P4. Perlakuan P1 diperoleh hasil berbeda nyata dengan perlakuan P0, P2,P3 dan P4. Perlakuan P2 diperoleh hasil berbeda nyata dengan perlakuan $\mathrm{P} 0$, P1, P3, dan P4. Ketentuan efektivitas dilihat berdasarkan standar pengujian efikasi insektisida yang dikeluarkan oleh Direktorat Pupuk dan Pestisida Departemen Pertanian, suatu formulasi insektisida dikatakan efektif bila pada sekurang-kurangnya $(1 / 2 \mathrm{n}+$ 1) kali pengamatan ( $\mathrm{n}=$ jumlah pengamatan) setelah aplikasi, tingkat efikasi insektisida tersebut lebih dari atau sama dengan 50\% ( $\geq 50 \%)$ dengan syarat populasi hama sasaran pada perlakuan insektisida yang diuji lebih rendah daripada populasi hama pada kontrol. Dikatakan bahwa suatu pestisida/insektisida nabati dinyatakan efektif jika sudah membunuh 50\% atau lebih dari larva uji. Sehingga dapat disimpulkan bahwa serai wangi(Andropogon nardus) dapat digunakan sebagai pestisida nabati/molluskisida yang efektif untuk memortalitaskanhama keong mas (Pomacea canicullata).

\section{PEMBAHASAN}

Pada penelitian terlihat bahwa semakin lama keong direndam maka mortalitas keong akan semakin tinggi (Gambar 1). Pada konsentrasi $0-3 \%$ keong masih melakukan aktifitas bergerak dan makan daun. Dalam hal ini keong yang masih hidup terpacu untuk makan lebih banyak guna memperoleh energi untuk mendetoksifikasi racun pada dosis sub letal yang masuk ke tubuhnya setelah terpapar ekstrak tanaman. Ekstrak bersifat toksik dan telah terakumulasi di dalam tubuhnya, sehingga pada pengamatan hari berikutnya jumlah daun yang dimakan lebih sedikit dan pada akhirnya keong tersebut mati. 
Pada konsentrasi $4 \%$ pergerakan keong emas yang mula-mula aktif menjadi sangat lamban. Daya makan keong emas mula-mula aktif menjadi berkurang. Sebanyak $100 \%$ keong mas mengalami kematian. Perubahan morfologi pada keong emas yang mati operkulum terbuka, mengeluarkan lendir dan tubuh keluar dari cangkang. Dari segi warna sebelum perlakuan, warna pada tubuh kuning cerah dan setelah perlakuan berubah menjadi kuning pucat kehitaman. Hal ini menunjukkan bahwa semakin banyak senyawa kimia pada sereh yang masuk dalam tubuh keong emas akibatnya semakin banyak jaringan yang dirusak sehingga menyebabkan kematian

Pada konsentrasi 5\% secara keseluruhan $(100 \%)$ keong mati semua. Hal ini berkaitan dengan lamanya keong mas terpapar ekstrak yang diuji. Pada gambar 2. dalam keadaan normal/sehat, Keong akan selalu menempel pada daun atau pada permukaan cawan petri, dan air tetap jernih dan tidak berbau walaupun tidak dilakukan penggantian air. Sebaliknya keong yang mati akan terbalik posisinya, dan operkulumnya terlepas dari cangkangnya.Terjadi perubahan warna pada tubuh di bagian atas operkulum berubah warna dari kuning terang menjadi kuning pucat kehitaman dan mengeluarkan lendir. Hal ini dikarenakan senyawa kimia pada serai merusak enzim glutationase sehingga terjadi kerusakan pada selaput lendir, tubuh keluar dari cangkang, mengeluarkan exudat/lendir yang berbau busuk. Diduga exudat tersebut larut dalam air sehingga air yang semula jernih berubah menjadi keruh dan berbau busuk dan bewarna kehitaman. Hal ini sesuai dengan pernyataan Henny dkk, (2011) bahwa lamanya perendaman akan mempengaruhi aktivitas makan keong mas uji. Semakin lama keong direndam aktivitas makannya semakin menurun. Hasil penelitian lain yang berkaitan, bahwa perlakuan konsentrasi bawang putih memberikan pengaruh yang sangat nyata terhadap penghambatan makan keong mas. Semakin tinggi konsentrasi ekstrak bawang putih yang diberikan semakin tinggi pula persentase penghambatan makan keong mas. Hal ini membuktikan bahwa semakin tinggi tingkat kepekatannya semaki tinggi bahan aktif yang dikandungnya, dengan demikian semakin tinggi pula daya bunuhnya (Rusdy, 2010). Kandungan serai wangi terdapat sitronella (35,97\%), Nerol $(17,28 \%)$, sitronelol $(10,03 \%)$, geranyle acetat $(4,44 \%)$, elemol $(4,38 \%)$, limonene $(3,98 \%)$ dan citronnellyle acetate $(3,51 \%)$. Senyawa sitronella mempunyai sifat racun dehidrasi (Rusdy, 2010). Racun tersebut merupakan racun kontak yang dapat mengakibatkan kematian karena serangga akan mengalami kekurangan cairan. Tanaman ini dapat digunakan sebagai pengganti pestisida kimia (Budiarsih, 2011).Menurut Subiakto (2002) konsentrasi zat racun yang terkandung di dalam larutan sesuai dengan jumlah konsentrasi bahan yang digunakan, jika konsentrasi bahan yang digunakan banyak maka konsentrasi zat racun yang terkandung didalam larutan akan tinggi, begitu juga sebaliknya. Daya racun yang dimiliki oleh senyawa pestisida disebut toksisitas. Faktor yang mempengaruhi sifat racun dari pestisida adalah: 1) Toksisitas dari senyawa pestisida. 2) Penggunaan konsentrasi pestisida. 3) Lamanya terkena pestisida pada tanaman yang dilakukan pengendalian. 4) Mekanisme pestisida masuk kedalam tubuh tanaman (Kurniawati, 2007). 


\section{KESIMPULAN}

Berdasarkan hasil penelitian pengaruh variasi konsentrasi ekstrak serai (andropogon nardus) terhadap mortalitas hama keong mas Pomaceacaniculata L, maka dapat disimpulkan bahwa : Konsentrasi yang paling efektif dalam membunuh hama keong mas Pomaceacaniculata Ladalah 5\% yang mampu membunuh 100\%hama keong mas Pomaceacaniculata L selama 24 jam. Senyawa sitronela mempunyai sifat racun kontak yang dapat mengakibatkan kematian karena kehilangan cairan terus menerus. Dari hasil penelitian tersebut dapat digunakan Sebagai Sumber Belajar Peserta Didik untuk Meningkatkan Materi Pencemaran Lingkungan Kelas $X$ SMA Semester Genap.

\section{SARAN}

Perlu dilakukan penelitian lebih lanjut tentang aplikasi ekstrak serai (andropogon nardus L)pada skala lapangan.

\section{Daftar Pustaka}

Ben-Ami, F. Heller, J. 2004. Biological control of aquatic pest snails by the black carp Mylopharyngodon piceus. Biological Control 22:131-138

Budiarsih, S.K. 2011. Makalah Program PPM Pemanfaatan Beberapa Tanaman yang Berpotensi Sebagai Bahan Anti Nyamuk. Yogyakarta: UNJ.
Budiyono S. 2006. Teknik mengendalikan keong emas pada tanaman padi. Jurnal Ilmu-Ilmu Pertanian. Volume; 2 (2): hal; $128-133$

Direktorat Pupuk dan Pestisida Departemen Pertanian. 2010. Pedoman Teknis Penggunaan Pestisida. Jakarta

Henny., Makal., \& Turang, D. 2011. Pemanfaatan Ekstrak Kasar Batang Serai Untuk Pengendalian Larva Crosidolomia binotalis Zell.Pada Tanaman Kubis. Manado: Universitas Sam Ratulangi.

Kardinan, A. 2004. "Biopestisida Ramuan dan Aplikasi”. Halaman 6-7. ISBN 9793357290. Penebar Swadaya. Jakarta.

Kurniawati, dkk, 2007."Keong Mas Dari Hewan Peliharaan Menjadi Hama Utama Tanaman Padi". Balai Besar Tenelitian Tanaman Padi.

Riyanto, 2003. Aspek- Aspek Biologi Keong Mas (Pomacea canaliculata L.). Jurnal FORUM MIPA Vol. 8 No. 1 Edisi Januari 2003, hal 20-26. ISSN 14101262.

Rusdy, A. 2010. "Pengaruh Pemberian Ekstrak Bawang Putih Terhadap Mortalitas Keong Mas". Jurnal. J.Floratek 5: 172-180. Unsyiah Banda Aceh

Subiakto, S. 2002. Pestisida Nabati Pembuatan dan Pemanfaatan. Balai Penelitian Tanaman Holtikultura. Jakarta. 